From the Faculty of Veterinary Medicine, University of Nairobi, Nairobi, Kenya, Institute of Pharmacology, University of Oslo, Oslo, Norway, and Department of Pharmacology and Toxicology, Norwegian College of Veterinary Medicine, Oslo, Norway.

\title{
Effect of a Glucocorticoid on the Post-Operative Course Following Experimental Orthopaedic Surgery in Dogs
}

\author{
By S. W. Mbugua, L. A. Skoglund, P. Skjelbred and P. Løkken
}

\begin{abstract}
Mbugua, S. W., L. A. Skoglund, P. Skjelbred and P. Lokken: Effect of a glucocorticoid on the post-operative course following experimental orthopaedic surgery in dogs. Acta vet. scand. 1988, 29, 43-49. - The capability of a single i.m. injection of betamethasone (Celeston Chronodose ${ }^{\star}$ ) to modulate a post-operative course was investigated in a placebo-controlled crossover trial with 8 dogs. Two widentical « soft tissue/bone operations were performed on the forelimbs of each animal with an interval of 28 days, to allow a paired comparison of the inflammatory signs and healing process. Significantly less swelling, but not less pain and limping, was observed when the glucocorticoid was administered. No adverse effect of the glucocorticoid was seen on wound and bone healing. The present experimental model is suggested useful for evaluation of anti-inflammatory drug effects in accidental trauma and orthopaedic surgery.
\end{abstract}

betamethasone; post-operative swelling; pain; limping; wound and fracture healing.

\section{Introduction}

In accidental trauma and surgery various antiphlogistic measures have been instituted based on the rationale that the inflammatory process, in many instances, overshoot its objective as a defence and repair response ( $A$ llgöwer \& Perren 1967). The selection of antiinflammatory drugs to alleviate pain and excessive inflammatory responses seems too often to have been based on results obtained in experimental models designed to evaluate drugs which have shown beneficial effects in rheumatoid conditions, or clinical experiences in such patients (Løkken \& Skjelbred 1981). Since, however, the acute inflammatory reaction after surgery and trauma differs markedly from the rheumatoid type of inflammation, it is not surprising that the two types may be differently affected by an- ti-inflammatory drugs. Recent controlled studies with bilateral oral surgery in humans revealed that drugs such as acetylsalicylic acid, oxyphenbutazone and ibuprofen which efficiently reduce rheumatoid swelling, had little or no effect on post-operative swelling, while paracetamol which often has been claimed to be without anti-inflammatory activity, reduced the swelling by about $30 \%$ (Løkken et al. 1975, Album et al. 1977, Løkken \& Skjelbred 1980, Skjelbred 1984). A single injection of a glucocorticoid proved even more efficient and reduced the swelling by about $50 \%$ and in addition gave a striking pain relief (Skjelbred \& Løkken 1982 a, Skjelbred \& Løkken 1982 b, Skjelbred \& Løkken 1983). Conclusions obtained from oral surgery may not necessarily apply to surgery 

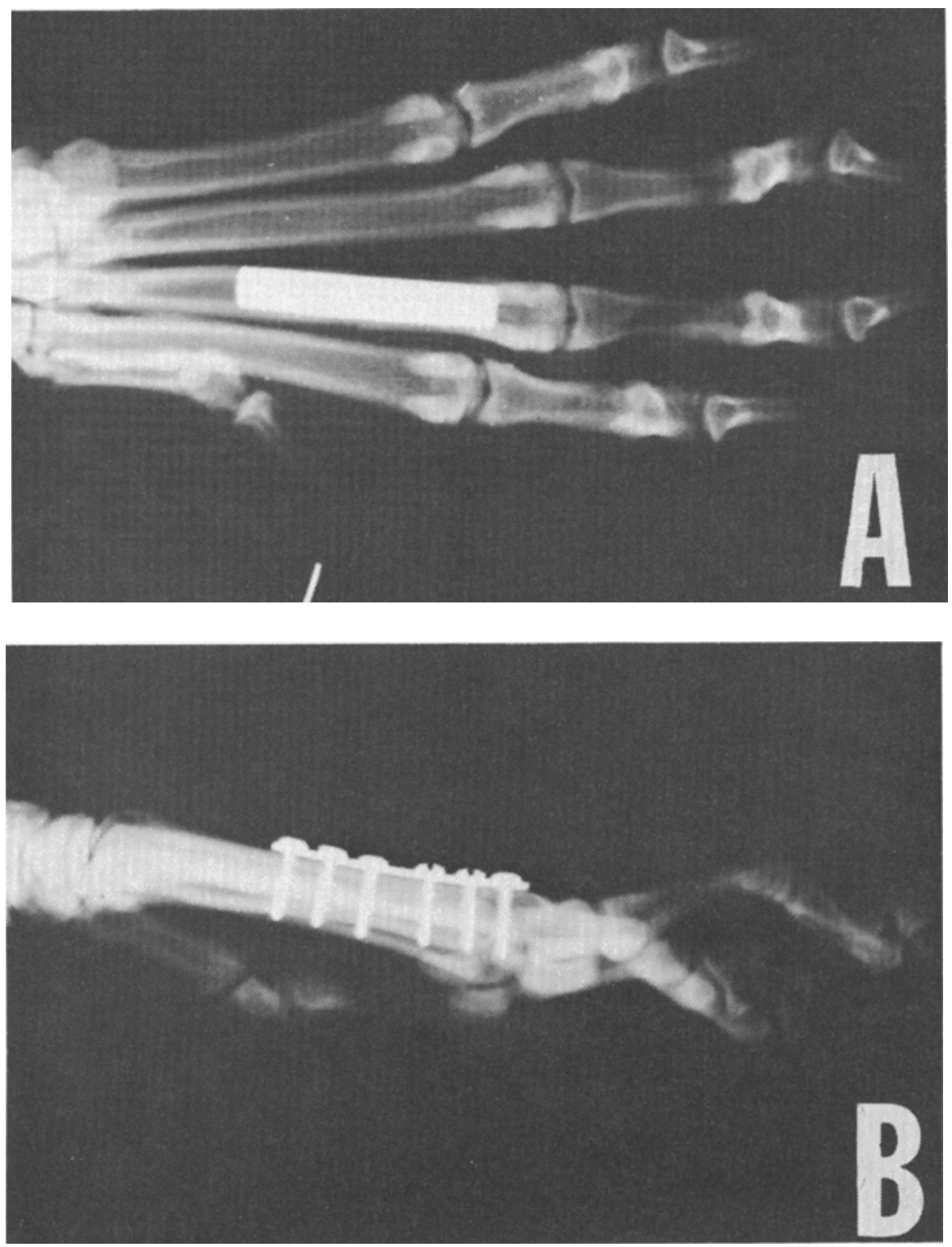

Figure 1. Post-operative radiographs of the distal forelimb showing the fixation $(\mathrm{A}=$ dorsal view, $\mathbf{B}=$ lateral view). 
and trauma in other parts of the body (e.g. the extremities) or to other species.

The aim of the present work was to establish a model in dogs which could show how steroidal and non-steroidal drugs may modulate the course of the healing process after standardized soft tissue and bone injuries. It was to be ascertained whether the observations obtained from surgical intervention on the extremities of dogs would be comparable to those obtained in oral surgery in humans. The use of experimental animals would allow histological examination of the healing process.

\section{Material and methods}

Experimental design

The trial was carried out as a randomized, placebo-controlled crossover study with two »identical" surgical soft tissue/bone interventions performed on the forelimbs of each animal with an interval of 28 days to allow a paired comparison of the post-operative courses.

\section{Animals}

Eight mongrel dogs of either sex and without verifiable diseases, weighing from 15 to 20 $\mathrm{kg}$, were used. The ethical aspects of the study were approved and supervised by the relevant authority at the Faculty of Veterinary Medicine, University of Nairobi.

\section{Drugs}

Immediately before each operation a single dose of $3 \mathrm{mg}$ betamethasone $(0.5 \mathrm{ml}$ Celeston Chronodose ${ }^{\circledast}$, Schering Corp., USA) or placebo $(0.5 \mathrm{ml}$ saline) was injected into the upper thigh muscles. The randomization system ensured that half of the animals received the active drug before the first operation. To keep the trial blind to the surgeon, the injections were administered by an assistant who had no other responsibility in the trial.

\section{Surgical procedure}

The operations were carried out under general thiopentone/halotane anaesthesia after premedication with acetylpromazine and atropine. After routine preparations for aseptic surgery, a skin incision was made dorsally over the third metacarpus. The metacarpus was then transected at about the midpoint with an oscillating saw (AMSCO Hall Surgical, Santa Barbara, USA). The transection was stabilized (Fig. 1) with a 6 hole DCP (mini Dynamic Compression Plate, Synthes ${ }^{\circledast}$, Waldenburg, Switzerland), and finally the wound was sutured.

\section{Assessments}

Swelling was recorded by measuring the water displaced by the limb (Fig. 2). The limb was emerged in a cylinder filled with water, until a mark on the shaved skin of the limb reached the top of the cylinder. This exercise was made pre- and post-operatively and the difference in volume of water recorded. The average of three successive measurements was used to represent the volume of the dog's limb. Pain was assessed by the surgeon who exerted digital pressure on the site of surgery and marked on a visual analogue

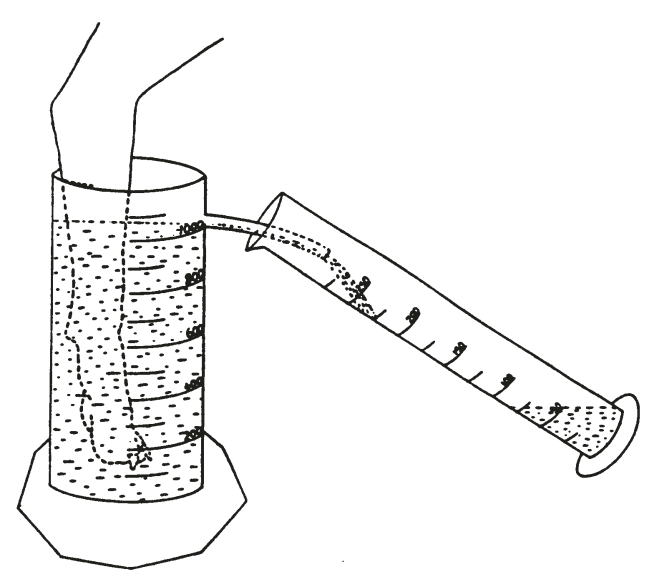

Figure 2. Device for volumetry of the forelimb. 
scale (VAS) that ran from »no pain « $(0 \mathrm{~mm})$ to "severe pain« $(100 \mathrm{~mm})$. Limping was marked on a $100 \mathrm{~mm}$ VAS running from $»$ no limping " to »severe limping «, These assessments were made between 8 and 9 a.m. every day for a week after each operation, and any abnormalities in wound healing were also recorded. Bone healing was monitored by radiographs taken $0,2,4,6$ and 8 weeks after each operation. The dogs were euthanized ( $18 \%$ pentobarbitone) 8 weeks after the second operation, and the two 3rd metacarpi of the forelimbs excised. The DCP's and screws were removed and the metacarpi placed in $10 \%$ buffered formalin for at least $24 \mathrm{~h}$. The metacarpi were immersed in a $1 \% \mathrm{w} / \mathrm{v}$ gel of sodium carboxymethylcellulose and frozen in a bath of $n$-hexane cooled to $-75 \mathrm{C}$. Sagittal sections were cut from the metacarpi at three levels through the site of surgery in a cryomicrotome (PMV 450 MP, PMV, Sweden) at $-20 \mathrm{C}$ and stained with hematoxylin eosin (HE) according to standard procedure (Fig. 3). The sections were subsequently assessed by light microscopy for discrepancies in the bone healing.

\section{Statistical analysis}

Statistical analysis was performed with a one-sided Wilcoxon signed rank test with correction for ties. A significance level of $5 \%$ was used.

\section{Results \\ Swelling}

The administration of betamethasone resulted in significantly less swelling during the first 3 days after the operation (Table 1). On the first post-operative day the swelling was reduced to $34 \%$ of the placebo with betamethasone. Furthermore, betamethasone reduced swelling to $42 \%$ and to $57 \%$ of the placebo on the second and third post-operative day, respectively.

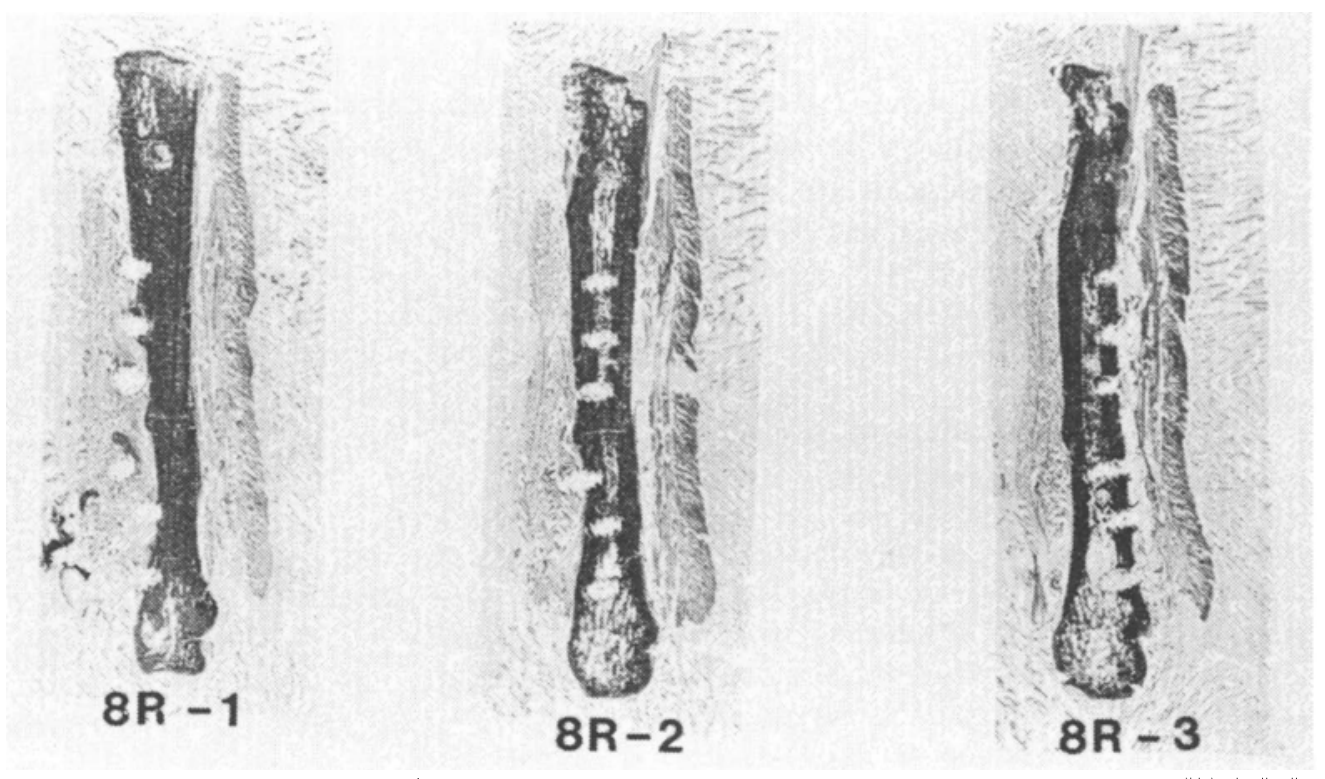

Figure 3. Sections of the 3rd metacarpus at 3 levels 8 weeks after surgical transection. 
Table 1. Post-operative swelling in $\mathrm{ml}$ displaced water measured by limb volumetry in 8 dogs injected with $3 \mathrm{mg}$ betamethasone and placebo in a crossover trial.

\begin{tabular}{llccccccc}
\hline & & \multicolumn{7}{c}{ Day } \\
\cline { 2 - 8 } & & 1 & 2 & 3 & 4 & 5 & 6 & 7 \\
\hline \multirow{3}{*}{ Betamethasone } & Mean & 12 & 13 & 20 & 25 & 29 & 24 & 22 \\
& Median & 10 & 16 & 22 & 25 & 36 & 28 & 24 \\
& $95 \%$ conf. int. & $2-21$ & $5-22$ & $13-28$ & $15-36$ & $19-39$ & $12-35$ & $9-31$ \\
& Range & $-5-27$ & $-5-27$ & $8-32$ & $6-42$ & $11-42$ & $1-42$ & $-10-34$ \\
& Increase of & & & & & & & \\
& limb volume (\%) & 8 & 9 & 14 & 18 & 21 & 17 & 15 \\
\hline \multirow{3}{*}{ Placebo } & Mean & 35 & 31 & 35 & 30 & 30 & 32 & 28 \\
& Median & 30 & 32 & 31 & 29 & 29 & 32 & 29 \\
& 95\% conf. int. & $23-46$ & $21-41$ & $22-48$ & $18-42$ & $21-39$ & $26-39$ & $18-38$ \\
& Range & $19-56$ & $9-55$ & $12-69$ & $10-59$ & $15-55$ & $22-48$ & $10-51$ \\
\hline P values & Increase of & & & & & & & \\
& limb volume (\%) & 25 & 23 & 25 & 22 & 22 & 23 & 20 \\
\hline
\end{tabular}

N.S. = not significant

\section{Pain}

There was no statistically significant difference between betamethasone and placebo treatment with respect to pain during the post-operative trial period.

\section{Limping}

There was no statistically significant difference between betamethasone and placebo treatments with respect to limping during the post-operative trial period.

\section{Wound and bone healing}

No noticeable differences were observed in the wound and bone healing, either by clinical examination or when the 2 sets of radiographs and histological sections after the 2 operations were compared.

\section{Discussion}

A single injection of $3 \mathrm{mg}$ betamethasone reduced the post-operative swelling significantly during the first three post-operative days. On the third post-operative day the mean reduction was $43 \%$ compared to placebo. Review of the literature shows few controlled clinical trials studying the effect of short-term glucocorticoid administration on the post-surgical or post-traumatic course (Swartz \& Dluhy 1978). The reports that glucocorticoid administration reduces the swelling after oral surgery by about $50 \%$ on the third post-operative day (Skjelbred \& Løkken 1982 a, Skjelbred \& Lokken 1982 b, Skjelbred \& Løkken 1983), agree with the present finding. In some other experiments with animals, glucocorticoids have also been shown to reduce post-traumatic swelling. Traumatic oedema of the rat ear pinna was reduced by $29 \%$ after medication with hydrocortisone (Marek \& Blaha 1980), and dexamethasone reduced the swelling significantly in replanted rat legs (Colen et al. 1979).

While the reduction of swelling was significant, neither the reduction of pain nor limping reached a level of significance. The lack of significant pain relief is in accordan- 
ce with the common view that glucocorticoids do not have analgesic effects (Huskisson 1984), but contrasts the findings in oral surgery (Skjelbred \& Lokken 1982 a, Skjelbred \& Løkken 1982 b, Skjelbred \& Løkken 1983). It was found difficult to obtain reliable and comparable estimates forpain and limping, in spite of the dogs being used as their own controls. These results should accordingly be interpreted with caution. Any adverse effects of the glucocorticoid on wound or bone healing were not detected. This agrees with the view that a single dose of a glucocorticoid is essentially safe and not likely to impair wound healing (Haynes \& Murad 1980, Schiller \& DeSilva 1979), while long term treatment is associated with numerous adverse effects. In rabbits, multiple doses of cortisone have been demonstrated to delay the healing of experimental fractures (Blunt et al. 1950, Sissons \& Hadfield 1951). There are several in vivo and in vitro experimental models that have achieved popularity for their ability to select drugs known to exert beneficial effects in rheumatoid conditions (Arrigoni-Martelli 1979). The in vivo models include adjuvant arthritis and related models with chronic inflammation. However, acute inflammation after surgery and injuries is basically a nonspecific and stereotyped reaction in contrast to the chronic inflammatory response which represents, in most cases, an immune reaction to antigenic substances (Ryan \& Majno 1977). Accordingly, anti-inflammatory drug effects are not necessarily the same in these different conditions. The same also applies to antiinflammatory drug effects on swelling after intraplantar or intrapleural injections of irritants such as carrageenin or kaolin, which may not be relevant for assessing effects on swelling after physical injuries (ArrigoniMartelli 1979). The present experimental osteotomy model should be more appropria- te for studying drug effects on the acute inflammatory reaction and the healing process after surgery and trauma.

\section{Acknowledgement}

This work was supported by the Norwegian Agency for International Development (NORAD). The authors are grateful to L. Sandvik, MSc, for performing the statistical analysis.

\section{References}

Album B, Olsen I, Løkken P: Bilateral surgical removal of impacted mandibular third molar teeth as a model for drug evaluation: A test with oxyphenbutazone (Tanderi ${ }^{\Phi}$ ). Int. J. Oral Surg. 1977, 6, 177-189.

Allgöwer M, Perren $S$ : The importance of inflammation in surgery. In: Bengmark, $S$. (ed) Inflammationen inom kirurgin. A Lindgren \& Söner AB, Göteborg 1967, pp. 10-20.

Arrigoni-Martelli E: Screening and assessment of antiinflammatory drugs. Meth. Find. Exp. Clin. Pharmcol. 1979, 1, 157-177.

Blunt J W, Plotz C M, Lattes P, Howes E L, Meyer $K$, Ragan $C$ : Effect of cortisone on experimental fractures in the rabbit. Proc. Soc. Exp. Biol. Med. 1950, 73, 678-681.

Colen L B, Crawley W A, Buncke $H$ J: Effect of parenteral steroids on edema in replanted rat legs. Plast. Reconstr. Surg. 1979, 63, 830-883.

Haynes $R$ C, Murad F: Adrenocorticotropic hormone; Adrenocortical steroids and their synthetic analogs; Inhibitors of adrenocortical steroid biosynthesis. In Gilman, A. G., Goodman, L. S. \& A. Gilman (eds) The Pharmacological basis of therapeutics. Bailliere Tindall, London 1980, p. 1466-1496.

Huskisson E C: Non-narcotic analgesics. In Wall, P. D. \& R. Melzack (eds) Textbook of pain. Churchill Livingstone, Edinburgh 1984, pp. 505-513.

Løkken P, Olsen I, Bruaset I, Norman-Pedersen K: Bilateral surgical removal of impacted lower third molar teeth as a model for drug evaluation: A test with ibuprofen. Eur. J. Clin. Pharmacol. 1975, 8, 209-216.

Løkken P, Skjelbred P: Analgesic and anti-inflammatory effects of paracetamol evaluated by bilateral oral surgery. Brit J. Clin. Pharmacol. 1980, supp 10, 253S-260S. 
Løkken P, Skjelbred P: Aspirin or paracetamol? Lancet, 1981, $i i$, 1346-1347.

Marek J, Blaha V: Traumatic oedema of the rat ear pinna: Its morphology and affection by some anti-inflammatory agents. Int. J. Tiss. React. 1980, 2, 95-206.

Ryan $G$ B, Majno: Acute inflammation. A review. Am. J. Pathol. 1977, 86, 185-276.

Schiller $R$, DeSilva J A: Postoperative steroid injection: The first seventy-two hours of bone healing. J. Am. Podiat. Assoc. 1979, 69, 364-366.

Sissons H A, Hadfield G J: The influence of cortisone on the repair of experimental fractures in the rabbit. Brit. J. Surg. 1951, 39, 172-178.

Skjelbred P: The effects of acetylsalicylic acid on swelling, pain and other events after surgery. Brit. J. Clin. Pharmocol. 1984, 17, 379-384.

Skjelbred P, Løkken P: Post-operative pain and inflammatory reaction reduced by injection of a corticosteroid. A controlled trial in bilateral oral surgery. Eur. J. Clin. Pharmacol. 1982 a, 21, 391-396.

Skjelbred P, Løkken P: Reduction of pain and swelling by a corticosteroid injected 3 hours after surgery. Eur. J. Clin. Pharmacol. 1982 b, 23, 141146.
Skjelbred P, Løkken P: Effects of naloxone on postoperative pain and steroid-induced analgesia. Eur. J. Clin. Pharma col. 1983, 15, 221-226.

Swartz $S$ L, Dluhy $R$ G: Corticosteroids: Clinical pharmacology and therapeutic use. Dru\&s. 1978, 16, 238-255.

\section{Sammendrag}

Effekt av et glucokortikoid pd det post-operative forlop etter eksperimentell ortopedisk kirurgi pd hunder.

Effekten av en i.m. injeksjon av betamethason (Celeston Chronodose ${ }^{\oplus}$ på det post-operative forløp ble undersøkt $i$ en placebo kontrollert overkryssningsstudie med 8 hunder. To »identiske« bløtvevs/hardvevs operasjoner ble utført pá forlabbene pá hvert dyr med 28 dagers mellomrom slik at en parvis sammenligning av det post-operative inflammatoriske forløp og tilheling kunne utføres. Det ble observert en statistisk signifikant reduksjon i helvelse, men ikke i smerte eller halting. Ingen bieffekter kunne sees pá sår eller bentilhelingen etter administrasjon av betamethason. Den presenterte forsøksmodell kan være til nytte for á evaluere legemidlers anti-inflammatoriske virkning pá forløpet etter aksidentelle traumer og ortopedisk kirurgiske inngrep.

(Received June 22, 1987).

Reprints may be requested from: Dr. S. W. Mbugua, Department of Clinical Studies, University of Nairobi, P. O. Box 29053 Kabete, Nairobi, Kenya. 
